\title{
EFEKTIVITAS MENULIS CERITA PENDEK DENGAN \\ MODEL PEMBELAJARAN MIND MAPPING \\ PADA MAHAMAHASISWA SEMESTER IV \\ PBSI STKIP PELITA BANGSA BINJAI \\ TAHUN PEMBELAJARAN 2016/2017
}

\author{
LASPINTA LUMBANBATU, M.PD. \\ Dosen STKIP Pelita Bangsa. Hp. 081396890930 \\ Alamat Kampus: Jl. Perintis Kemerdekaan No166 20744 Binjai. \\ Email:Llumbanbatulaspinta@,Gmail.com
}

\begin{abstract}
ABSTRAK
Penelitian ini bertujuan untuk meningkatkan kemampuan menulis cerpen dengan penerapan model pembelajaran Mind Mapping oleh mahamahasiswa semester IV Prodi Pendidikan Bahasa dan Satra Indonesia STKIP Pelita Bangsa Binjai Tahun Pembelajaran 2016/2017.Metode penelitian yang digunakan dalam penelitian ini adalah eksperimen pre-test post-test design. Populasi penelitian ini adalah seluruh mahamahasiswa semester IV STKIP Pelita Bangsa Binjai Tahun Pembelajaran 2016/2017. Mahasiswa dengan skor 70-75 akan dijadikan sebagai sampel. Dari sampel yang homogen ini secara random diambil sebanyak 40 orang menjadi sampel penelitian. Sampel yang paling cocok digunakan adalah berjumlah 40 orang. Data dianalisis untuk menguji hipotesis dengan rumus statistik uji-t. Dalam pengolahan data terlebih dahulu dilakukan uji persyaratan dengan uji normalitas data dengan menggunakan uji Liliefors dan uji homogenitas. Berdasarkan uji normalitas diperoleh $\mathrm{L}_{\text {hitung }}$ untuk pretes sebesar 0,125 dan postes 0,1163 dengan $\mathrm{L}_{\text {tabel }}$ sebesar 0,1402 sehingga $\mathrm{L}_{\text {hitung }}<\mathrm{L}_{\text {tabel }}$ dan hal ini membuktikan bahwa data berdistribusi normal. Selanjutnya uji homogenitas pretes diperoleh $\mathrm{F}_{\text {hitung }}=1,03$ dan $\mathrm{F}_{\text {tabel }}=1,69$ maka dapat disimpulkan bahwa data penelitian dinyatakan homogen karena $\mathrm{F}_{\text {hitung }}<\mathrm{F}_{\text {tabel }}$. Hasil pengujian hipotesis diperoleh yaitu $\mathrm{t}_{\text {hitung }}>\mathrm{t}_{\text {tabel }}$ yaitu $9,00>2,02$ pada taraf signifikan $5 \%$ dan $9,00>2,71$ pada taraf signifikan $1 \%$. Hal ini membuktikan bahwa hipotesis alternatif diterima. Dengan demikian, pembelajaran dengan menggunakan model pembelajaran mind mapping memiliki pengaruh yang signifikan. Kesimpulan, penerapan model pembelajaran mind mapping dapat meningkatkan kemampuan menulis cerpen oleh mahasiswa kelas semester IV Prodi Pendidikan Bahasa dan Satra Indonesia STKIP Pelita Bangsa Binjai Tahun Pembelajaran 2016/2017.
\end{abstract}

\section{PENDAHULUAN}

Pembelajaran sastra di perguruan tinggi negeri dan swasta diakui masih sangat minim dan kurang aktraktif. Kenyataan ini berdampak pada lemahnya apresiasi dan penghargaan mahamahasiswa prodi Pendidikan Bahasa dan Sastra Indonesia terhadap karya sastra. Pembelajaran sastra di kampus sering dianaktirikan. Dosen memandang mudah dan melewati atau tidak mengajarkan sastra dengan tuntas. Pembelajaran sastra dianggap tidak penting, menghabiskan waktu, dan tidak dapat mendongkrak nilai prestasi komulatif (IPK). Sebab, tugas-tugas yang terkait dengan materi sastra sangat sedikit dan dianggap mudah. Salah satu sebab diabaikannya pembelajaran sastra di kelas adalah langkanya media yang bisa dipakai untuk melaksanakan proses pembelajaran sastra. Sebagai contoh, ketika dosen mengajarkan materi menanggapi pembacaan cerpen, puisi, atau drama. Bila media itu tidak ada, pembelajaran menanggapi materi cerpen, puisi, atau drama tidak akan dapat dilaksanakan. Berarti, proses belajar mengajar sastra tidak dapat dilaksanakan. Kelangkaan media juga mengakibatkan pembelajaran 
sastra hanya difokuskan pada kegiatan yang bersifat hafalan.

Realitas yang dihadapi di prodi pendikan Bahasa dan Sastra Indonesia STKIP Pelita Bangsa Binjai mengenai pembelajaran sastra kurang diperhatikan dan tidak mendapat penanganan dengan baik, baik dari segi waktu, sarana, dan model pembelajaran. Dosen menganggap pembelajaran sastra hanya sebagai pelengkap matakuliah dari pembelajaran Bahasa Indonesia. Pembelajaran sastra yang merupakan integritas dari pembelajaran Bahasa Indonesia seharusnya diapresiasi dengan model pembelajaran yang inovatif sehingga mahasiswa mampu mengapresiasi karya sastra dengan baik. Pendek kata, pembelajaran sastra sangat penting yang bertujuan menumbuhkan rasa cinta terhadap karya sastra yang dapat diambil manfaatnya sebagai sarana pembentuk kepribadian dan moral.

Fenomena serupa terjadi pada STKIP Pelita Bangsa Binjai. Berdasarkan kegiatan PPL yang dilaksanakan selama 3 bulan di lokasi yang telah di tentukan dari pihak UPPL diketahui bahwa mahamahasiswa yang praktik di sekolah mengalami kenda dalam mengajarkan pembelajaran menulis cerpe. Mahamahasiswa kesulitan untuk mencari cara agar mahasiswa belajar secara aktif dan kreatif, lebih banyak memberikan teori tentang unsur intrinsik cerpen dan belum berani menugaskan mahasiswa untuk menulis cerpen. Mahamahasiswa hanya menugaskan mahasiswa yang berminat menulis cerpen yang akan dimasukkan ke majalah dinding atau majalah bulanan sekolah. Dari pihak mahasiswa diketahui bahwa kesulitan mahasiswa dalam menulis cerpen disebabkan oleh tidak adanya ide.

Untuk menyingkapi permasalahan tersebut diperlukan satu model pembelajaran yang dapat meningkatkan kualitas pembelajaran menulis cerpen. Diharapkan dengan peningkatan kualitas proses pembelajaran, hasil pembelajaran berupa keterampilan menulis cerpen mahasiswa pun meningkat. Pemetaan pikiran atau biasa dikenal dengan istilah mind mapping adalah salah satu model pembelajaran yang dapat digunakan untuk mengatasi masalah tersebut. Berakar dari kesulitan mahasiswa dalam memahami dan menerapkan unsur instrinsik dalam cerpen yang dibuatnya serta kesulitan dalam mengembangkan ide cerita dipilihlah model pemetaan pikiran (mind mapping). Model yang dipopulerkan oleh Tony Buzan ini merupakan model yang efektif untuk meningkatkan kemampuan menulis (www.google.com). Dalam model pemetaan pikiran (mind mapping) tersebut, pertama-tama mahasiswa menuliskan satu kata kunci dari tema yang dipilih di tengah kertas. Tema tersebut kemudian dijabarkan dalam rantingranting berupa unsur cerpen yang meliputi alur, penokohan, watak, setting, sudut pandang serta ending cerita yang telah dipilih. Pada dasarnya, dengan model ini, mahasiswa dituntun untuk membuat perencanaan sebelum menulis cerpen. Bila dalam perencanaan tulisan sering dikenal dengan pembuatan kerangka karangan, dalam pemetaan pikiran kerangka karangan tersebut berupa kata kunci yang dilengkapi dengan gambar berwarna yang dipetakan. Selain lebih menarik, kelebihan lain dari peta pikiran ini adalah mahasiswa dapat menambahkan kata kunci di mana pun jika di tengah kegiatan menulis ia mendapatkan ide baru. Pemetaan pikiran tersebut dapat terus berkembang sesuai dengan keinginan penulisnya. Dengan demikian, dalam model ini, mahasiswa dibebaskan untuk menulis "apa pun" sesuai dengan keinginan serta kreativitas. Di samping itu, simbol serta gambar berwarna yang digunakan berpotensi mengoptimalkan fungsi kerja otak kanan yang memacu kreativitas serta imajinasi sehingga diharapkan mahasiswa tidak kehabisan ide dalam menulis cerpen. Implikasi dari uraian di atas dalam kaitannya dengan penelitian ini adalah 
perlu diterapkannya model pemetaan pikiran (mind mapping) sebagai upaya meningkatkan kemampuan menulis cerpen pada mahamahasiswa semester IV STKIP Pelita Bangsa Binjai. Rumusan Permasalahan dari penelitian adalah 1) Bagaimanakah kemampuan mahamahasiswa semester IV STKIP Pelita Bangsa Binjai dalam menulis cerita pendek dengan model pembelajaran mind mapping? 2) Apakah penerapan model pembelajaran mind mapping dapat meningkatkan keterampilan mahamahasiswa menulis cerpen?

Penelitian ini bertujuan untuk mengetahui apakah model mind mipping dapat meningkatakan motivasi mahasiswa dalam menulis cerita pendek pada mahamahasiswa semester IV Prodi Pendidikan Bahasa dan Satra Indonesia STKIP Pelita Bangsa Binjai dan hasil keterampilan menulis cerita pendek mahasiswa dengan model mind mapping pada mahamahasiswa semester IV Prodi Pendidikan Bahasa dan Satra Indonesia STKIP Pelita Bangsa Binjai.

Adapun manfaat penelitian ini adalah sebagai berikut:

1. Manfaat Teoritis

Penelitian ini diharapkan dapat digunakan untuk memperkaya khasanah ilmu pengetahuan pembelajaran sastra khusunya pada aspek model alternatif pembelajaran menulis cerpen.

2. Manfaat Praktis

a. Bagi Mahamahasiswa

1) Pembelajaran menulis cerpen lebih bermakna.

2) Melatih mahamahasiswa untuk berpikir imajinatif dan kretif.

3) Meningkatkan kemampuan menulis cerpen mahamahasiswa.

b. Bagi Dosen

1) Meningkatkan kinerja dosen.

2) Mendorong dosen untuk melaksanakan pembelajaran yang inovatif kreatif.

3) Mengatasi permasalahan pembelajaran menulis cerpen yang dialami oleh dosen. c. Bagi Peneliti

1) Mengembangkan wawasan dan pengalaman peneliti.

2) Mengaplikasikan teori yang telah diperoleh.

\section{METODOLOGI PENELITIAN}

Metode memegang peranan penting dalam penelitian, agar apa yang menjadi tujuan penelitian dapat tercapai maka metode penelitian yang digunakan harus sesuai dengan masalah yang dibahas. Penelititan ini dilakukan untuk mengetahui Upaya Meningkatkan Kemampuan menulis cerpen dengan model pemebelajaran Mind Mapping mahamahasiswa semester IV Prodi Pendidikan Bahasa dan Satra Indonesia STKIP Pelita Bangsa Binjai Tahun Pembelajaran 2016/2017. Metode yang digunakan adalah metode kuasi eksperimen (eksperimen semu) dengan model one group pre- test post- test design.

Sesuai dengan judul penelitian, lokasi yang ditetapkan menjadi tempat penelitian yaitu mahamahasiswa semester IV Prodi Pendidikan Bahasa dan Satra Indonesia STKIP Pelita Bangsa Binjai .

Adapun yang menjadi populasi penelitian ini adalah seluruh mahamahasiswa semester IV Prodi Pendidikan Bahasa dan Satra Indonesia STKIP Pelita Bangsa Binjai Tahun Pembelajaran 2017/2018. Untuk mendapatkan sampel yang homogen beberapa pengontrolan akan dilakukan. Pengontrolan pertama dilakukan untuk menjaring sampel yang homogen. Dalam hal ini seluruh populasi akan diberikan pretest yaitu menulis karangan cerpen sederhana. Mahasiswa dengan skor 70-75 akan dijadikan sebagai sampel. Dari sampel yang homogen ini secara random diambil sebanyak 40 orang menjadi sampel penelitian. Dengan desain ini, besar efeknya dari eksperimen dapat diketahui dengan pasti karena sudah menggunakan tes awal. 
Tabel 1. Desain Eksperimen One Group Pre- Test Post- Test Design

\begin{tabular}{|c|c|c|c|}
\hline Kelas & $\begin{array}{c}\text { Pre- } \\
\text { test }\end{array}$ & Perlakuan & $\begin{array}{c}\text { Post- } \\
\text { test }\end{array}$ \\
\hline Eksperimen & $\mathrm{O}_{1}$ & $\mathrm{X}$ & $\mathrm{O}_{2}$ \\
\hline
\end{tabular}

\footnotetext{
Keterangan:

$\mathrm{O}_{1} \quad=$ pre-test (tes awal) menulis cerpen sebelum mendapat perlakuan

$\mathrm{X}=$ perlakuan dengan model pembelajaran Mind Mapping

$\mathrm{O}_{2} \quad=$ post-test (tes akhir) menulis cerpen sesudah mendapat perlakuan
}

Tes ini dilakukan untuk pre- test dan posttest. Pre- test digunakan untuk menjaring data kemampuan menulis cerpen sebelum diadakan perlakuan, sedangkan post- test digunakan untuk menjaring data kemampuan menulis cerpen setelah diadakan perlakuan yaitu, dengan menggunakan model pembelajaran Mind Mapping.

Data yang telah dikumpulkan selanjutnya akan dianalisis guna mencapai hasil yang maksimal. Langkah-langkah analisis tersebut dapat dilakukan dengan:

a. Memeriksa lembar kerja mahasiswa.

b. Mendeskripsikan nilai yang diperoleh.

c. Menyusun data pretes dan postes dalam bentuk tabel.

d. menghitung jumlah rata-rata dan standar deviasi data sampel, yaitu data pretes dan postes.

1. Menghitung nilai rata-rata menggunakan rumus:

$\operatorname{Mean}(\bar{x})=\frac{\sum f i . x i}{\sum f i}$

(Sudjana,

$2005: 70)^{5}$

Keterangan:

$\bar{X}=$ Rata-rata

$\sum$ fixi $=$ Jumlah dari hasil perkalian antara midpoint masing-masing interval dengan frekuensi

$\sum f i=$ Jumlah frekuensi untuk nilai xi yang bersesuaian

$\mathrm{N}=$ Jumlah sampel

2. Menghitung standar deviasi dari variabel hasil pretes dan postes dengan menggunakan rumus:

$$
\begin{aligned}
& S^{2}=\frac{\sum f_{i(x i-\ddot{x})^{2}}}{n-1} \\
& S=\sqrt{S^{2}}
\end{aligned}
$$

(Sudjana, 2005:95)

Keterangan:

$\mathrm{S}=$ Standar deviasi

$\mathrm{S}^{2}=$ Variansi

$\bar{X}=$ Rata-rata

$f i=$ Menyatakan frekuensi untuk nilai $\mathrm{x} i$ yang bersesuaian

$x i=$ Menyatakan nilai ujian

$\mathrm{N}=$ Jumlah sampel

\section{Uji Normalitas}

Uji ini dilakukan untuk mengetahui apakah populasi berdistribusi normal atau tidak. Pengujian normalitas ini menggunakan uji Liliefors (Sudjana, 2002:466) ${ }^{4} \quad$ dengan langkah-langkah sebagai berikut :

a. Data $\mathrm{X}_{1}, \mathrm{X}_{2}, \ldots \ldots \ldots . \mathrm{Xn}$ dijadikan bilangan baku $\mathrm{Z}_{1}, \mathrm{Z}_{2}, \ldots \ldots \ldots . \mathrm{Zn}$ dengan

rumus :

$$
Z i=\frac{X i-\bar{X}}{S}
$$

Keterangan :

$$
\begin{array}{ll}
\bar{X} & =\text { Rata-rata } \\
\mathrm{S} & =\text { Simpangan Baku Sampel }
\end{array}
$$

b. Untuk tiap angka baku dihitung dengan menggunakan daftar distribusi normal baku dan kemudian dihitung peluang dengan rumus :

$$
\mathrm{F}\left(\mathrm{Z}_{1}\right)=\mathrm{P}\left(\mathrm{Z} \leq \mathrm{Z}_{1}\right)
$$

c. Menghitung proporsi $Z_{1}, Z_{2}, \ldots \ldots . Z n$ yang lebih kecil atau sama dengan 
Zi jika proporsi ini dinyatakan oleh $\mathrm{s}(\mathrm{zi})=\mathrm{p}(\mathrm{Z} \leq \mathrm{Zi})$ maka:

$\mathrm{S}(\mathrm{Zi})$

$\frac{\text { Banyak } Z_{1}, Z_{2}, \ldots \ldots . \text {. } n \text { yang } \leq Z_{1}}{n}$

d. Menghitung selisih $F\left(Z_{1}\right)-S\left(Z_{1}\right)$, kemudian menetapkan harga mutlaknya.

e. Ambil harga yang paling besar antara harga selisih tersebut dengan

$\mathrm{L}_{\mathrm{o}}$ : berdistribusi normal jika harga

$\mathrm{L}_{\mathrm{o}}<\mathrm{L}_{\mathrm{t}}$ dengan taraf nyata $\alpha=0,05$.

4. Uji Homogenitas

Uji homogenitas dilakukan untuk mengetahui apakah sampel yang diambil memiliki varians yang homogen atau tidak. Untuk pengujian ini digunakan uji Varians:

$\mathrm{F}=\frac{\text { VariansTerbesar }}{\text { VariansTerkecil }}$ atau

$\mathrm{F}=\frac{S^{2}{ }_{1}}{S^{2}{ }_{2}}(\text { Sudjana, } 2005: 250)^{5}$

\section{Uji Hipotesis}

Uji hipotesis penelitian dilakukan dengan menggunakan uji " $t$ " dengan rumus sebagai berikut.

$$
t=\frac{\bar{X}_{1}-\bar{X}_{2}}{s \sqrt{\frac{1}{n_{1}}}+\frac{1}{n_{2}}}
$$

$239)^{5}$

(Sudjana, 2005 :

$$
S=\frac{\left(n_{1}-1\right) S_{1+}^{2}\left(n_{2-1}\right) S_{2}^{2}}{n_{1}+n_{2}-2}
$$

Keterangan:

$\mathrm{t}=$ Distribusi $\mathrm{t}$

$\bar{X}_{1} \quad=$ Nilai rata-rata pada kelompok

setelah eksperimen

$\bar{X}_{2}=$ Nilai rata-rata pada kelompok sebelum eksperimen

$n_{1} \quad=$ Jumlah sampel pada kelompok setelah eksperimen

$n_{2} \quad=$ Jumlah sampel pada kelompok sebelum eksperimen

Kriteria pengujian ini adalah Ho jika $t_{0}>t_{t}$ pada taraf signifikansi $5 \%$ maka hipotesis penelitian (Ha) diterima. Dan sebaliknya jika $t_{0}<t_{t}$ pada taraf signifikansi 5\% maka hipotesis penelitian (Ha) ditolak dan Ho diterima.

\section{HASIL IMPLEMENTASI DAN PEMBAHASAN}

Setelah melakukan prosedur penelitian seperti uji normalitas, homogenitas, dan hipotesis akhirnya didapatkan sebuah penelitian yang hasilnya memiliki manfaat. Berdasarkan hasil penelitian, maka diperoleh temuan penelitian sebagai berikut:

1. Kemampuan tes awal mahamahasiswa atau pretes tanpa menggunakan perlakuan dengan nilai mahasiswa terendah 50 dan setelah diberi perlakuan dengan model pembelajaran mind mipping atau postes menjadi 60 . Dan nilai mahamahasiswa yang nilai prestasinya tertinggi sebelum diberikan perlakuan adalah 80 , kemudian setelah diadakan perlakuan dengan model pembelajaran mind mipping nilai postesnya menjadi 90. Dengan nilai rata-rata pretes 65 sedangkan nilai ratarata postes 74 . Hal ini membuktikan bahwa adanya peningkatan yang signifikan, yaitu dari rata-rata tes awal 65 menjadi 74 sebagai tes akhir.

2. Mahasiswa yang sebelumnya kurang paham dan kurang aktif dalam proses pembelajaran menulis cerpen, menjadi lebih baik dan aktif. Kesulitan mahamahasiswa dalam menulis cerpen dapat teratasi dengan model pembelajaran mind mapping karena dalam pembelajaran ini mahasiswa dituntut lebih aktif, terampil, serta mandiri.

3. Pengujian hipotesis, yaitu bahwa $\mathrm{t}_{\text {hitung }}$ $>\mathrm{t}_{\text {tabel }}$ yaitu 9,00>2,02 pada taraf signifikan $5 \%$ dan $9,00>2,71$ pada taraf signifikan $1 \%$. telah membuktikan bahwa hipotesis alternatif (Ha) diterima. Dengan demikian, pembelajaran dengan menggunakan model pembelajaran mind mapping 
berpengaruh signifikan terhadap peningkatan kemampuan menulis cerpen oleh kelas semester IV Prodi Pendidikan Bahasa dan Satra Indonesia STKIP Pelita Bangsa Binjai Tahun Pembelajaran 2016/2017.

Berdasarkan hasil penelitian dapat diketahui ternyata terdapat pengaruh yang signifikan pada penggunaan model pembelajaran mind mapping terhadap peningkatan kemampuan menulis cerpen oleh semester IV Prodi Pendidikan Bahasa dan Satra Indonesia STKIP Pelita Bangsa Binjai Tahun Pembelajaran 2016/2017. Awalnya (pretes) masih banyak mahasiswa yang kurang mampu menulis cerpen secara tepat sesuai dengan ketentuan. Mahasiswa cenderung mengalami kesulitan terbukti dari hasil pretes (sebelum diterapkan model pembelajaran mind mapping) peneliti mendapatkan data rata-rata nilai 65 , namun setelah diterapkan perlakuan (model pembelajaran mind mapping) maka hasil yang signifikan dapat diperoleh peningkatan yaitu mencapai rata-rata 74 . Hasil ini meyakinkan pernyataan bahwa Model yang dipopulerkan oleh Tony Buzan ini merupakan model yang efektif untuk meningkatkan kemampuan menulis. ${ }^{1}$

Peningkatan nilai rata-rata diperoleh karena. Mahamahasiswa semakin termotivasi dengan adanya model pembelajaran mind mapping yang menantang. model pembelajaran mind mapping telah mengubah kelas yang pasif menjadi aktif. Mahamahasiswa sangat berantusias menciptakan cerpen yang sesuai dengan ketentuan. Seperti pendapat Nurani bahwa mind mipping (1) lebih jelas lagi digunakan untuk hal-hal yang bersifat: menggambarkan sesuatu, (2) menjelaskan sesuatu proses, (3) mengkaji atau menganalisis suatu system, menggambarkan dari suatu situasi, (5) bersifat memprediksi suatu keputusan (Nurani, 2010: 26). ${ }^{2}$

Dari pengujian hipotesis juga telah membuktikan bahwa penerapan model pembelajaran mind mapping sangat berpengaruh signifikan dalam meningkatkan kemampuan mahasiswa dalam menulis cerpen. Sehingga apabila pada kesempatan lain mahasiswa ditugaskan lagi untuk menulis cerpen maka akan lebih mudah dipahami mahasiswa dan ini merupakan pengaruh dari proses pembelajaran yang telah dilakukan bersama-sama sebelumnya dalam satu kelas. Hasil tersebut meyakinkan pendapat Nadler (1988) (dalam Sanjaya, 2009:82) menjelaskan bahwa "Model yang baik adalah model yang dapat menolong si pengguna untuk mengerti dan memahami suatu proses secara mendasar dan menyeluruh."3

\section{SIMPULAN}

Penelitian ini bertujuan untuk mengetahui pengaruh model pembelajaran mind mapping terhadap kemampuan menulis cerpen. Setelah melalui proses penelitian dan berdasarkan analisis terhadap data-data yang ada maka dapat disimpulkan beberapa hal yang merupakan inti dari hasil penelitian ini.

1. Terjadi peningkatan hasil rata-rata dari kemampuan menulis cerpen pada mahasiswa yang menjadi objek penelitian.

2. Dengan memberikan dua kali perlakuan yang berbeda atas model pembelajaran tetapi terhadap mahasiswa yang sama, diperoleh hasil bahwa adanya perbedaan hasil belajar yang sangat signifikan.

3. Sebelum diberlakukannya model pembelajaran mind mapping nilai ratarata dari hasil menulis cerpen adalah 65 tetapi setelah diberikan perlakuan dengan model pembelajaran mind mapping maka diperoleh nilai rata-rata hasil belajar mahasiswa dalam menulis cerpen adalah 74 .

4. Penerapan model pembelajaran mind mapping yang baik adalah model pembelajaran mind mapping yang bermanfaat untuk peningkatan kemampuan menulis cerpen, yang mana 
sebelumnya mahasiswa kurang menunjukkan hasil yang memuaskan jika dilihat dari hasil yang diperoleh pada saat pretest.

5. Dengan adanya hasil penelitian ini yang secara hitungan statistika dengan menggunakan uji-t telah terbukti bahwa hipotesis awal penelitian ini dapat diterima, maka dapat dijadikan refrensi bahwa model pembelajaran mind mapping dapat diterapkan dalam meningkatkan kemampuan menulis cerpen.

Adapun saran yang dikemukakan penulis kepada para pembaca atau pihakpihak terkait lainnya atas penelitian ini adalah sebagai berikut:

1. Dalam menulis cerpen dengan mengunakan model pembelajaran mind mapping harus diimbangi dengan memberikan latihan yang maksimal.

2. Selain penggunaan media pembelajaran, dosen juga perlu memperhatikan strategi pembelajaran yang tepat dan menarik.

3. Selanjutnya bagi rekan-rekan mahamahasiswa khususnya mahamahasiswa kedosenan semoga hasil penelitian ini dapat dijadikan masukan bagi rekan-rekan bila ingin melakukan penelitian lebih lanjut terkait dengan model pembelajaran mind mapping .

\section{DAFTAR PUSTAKA}

DePorer, Bobbi dan Mike Hernackki. Quantum Learning: Membiasakan Belajar Nyaman dan Menyenangkan. Bandung: Kaifa.

Nurani, Yuliani, 2010. Mengajar dengan Portofolio. Jakarta: PT. Indeks.

Sanjaya, Wina. 2009. Kurikulum dan Pembelajaran: Teori dan Praktik Pengenbangan KTSP. Jakarta: Kencana.

-----------. 2002. Metode Statistika. Bandung: Tarsito.

Sudjana. 2005. Metode Statistika. Bandung: Tarsito. 